\title{
COVID-19 Tourist Seasons and Business Activities of Listed Hotel Companies in Croatia
}

\author{
VLASTA ROŠKA \\ Libertas International University, \\ Zagreb, Trg J. F. Kennedy 6 b \\ CROATIA
}

\begin{abstract}
The spread of the COVID-19 pandemic has caused an interruption to everyday life and the economy. In many countries, as in Croatia, tourism revenues account for one-fifth of the GDP, so any reduction in tourism revenues significantly impacts the economy. In Croatia, the peak season, July and August in 2020, was 54 percent and in 2021 was 84 percent of 2019 arrivals due to a better epidemiological situation. Based on the result of listed companies in the touristic sector on the Zagreb Stock Exchange in 2020, a multiple regression analysis defined a common indicator for detecting business results. The model of the common indicator is based on the ROE indicator, the ratio of business revenue and total assets and financial strength. The entire economy, especially the hotel industry, cannot survive the COVID-19 crisis without government support measures.
\end{abstract}

Key-Words: - COVID-19 crisis, Financial Strength, Financial result, Revenue, ROE, Total Asset Turnover Ratio,

Received: April 3, 2021. Revised: September 15, 2021. Accepted: October 15, 2021. Published: October 25, 2021.

\section{Introduction}

The second year of the global pandemic COVID19 crisis is passing. Life worldwide is starting to normalise, but only with COVID certification or vaccinated people. At the end of 3Q 2021, the world is going through the fourth wave of the corona crisis. The whole economy is feeling the effects of the corona crisis, and the tourism sector in particular.

The 2021 tourist season is far better than the 2020 season, primarily due to the invention of the covid vaccine for many tourist destinations. In addition, Croatia took advantage of the touristic season due to a better epidemiologic situation than their concurrent in 2021.

In the spring of 2020, almost all countries in the world introduced restrictive epidemiological measures to curb the spread of the coronavirus pandemic, primarily with total or partial lockdown, international travel restrictions and border closures. By mid-April 2020, almost 96 percent according the UNWTO [1] of all world destinations had introduced some form of restriction on the arrival of foreign travellers. Furthermore, tourist traffic declined in all tourist destinations, as well as in Croatia, due to the global pandemic COVID-19 crisis in 2020.

In Croatia, these measures have included partial lockdown, closing borders, restricting travel, adopting social distancing policies, banning large gatherings and events, closing restaurants, bars and other catering activities. These measures have, imminently and significantly, negatively affected the hotel market, with many cancelled reservations and guest absences. After the easing of measures, which happened in three phases in Croatia, the tourism business began its work in mid-May. As the reservations arrived, hotels also opened some of their facilities from May to July 2020. As a result, the number of tourist nights in 2020 compared to 2019 decreased in all groups in commercial accommodation. In 2020, there were 7.0 million tourist arrivals and 40.8 million tourist nights in commercial accommodation establishments, which was 64.2 percent fewer arrivals and 55.3 percent fewer nights than in 2019 [2]. By tourists from Germany (33.0 percent), Slovenia (13.28 percent), Poland (12.43 percent), and other neighbouring countries realised the most foreign tourist nights in 2020.

In 2020, Croatia achieved 50 percent of the result in 2019 , measured by overnight stays. When it finally seemed that the tourist season would exceed initial expectations due to an increase in the number of infected in August 2020, some countries put Croatia in the red zone in the second half of August, and foreign guests had to leave Croatia or cancel reservations. In the first year of the coronavirus pandemic, the number of tourist nights returned to the level of 20 years ago in Croatia [2]. Due to the 
significant impact of seasonality and high sensitivity of the tourism sector to the corona crisis, this paper aims to:

1) investigate how the corona crisis affected the business operations of hotel companies listed on the Zagreb Stock Exchange based on the 2020 results;

2) examine the situation in the tourism sector during the peak season in two pandemic years.

The following hypotheses are:

H1: The corona crisis has caused the deterioration of the business of listed hotel companies almost to the point of closing companies in 2020

$\mathrm{H} 2$ : There is a statistically significant correlation between the government support in corona crises and financial results

H3: There is a statistically significant correlation between the number of tourists in arrivals and nights, GPF, Inflation and ECDC Zone.

The paper consists of six (5) parts including, the introduction and the conclusion. The remainder of the paper is organized as follows. Section 2 recalls the literature of theoretical and empirical studies that have examined various factors of COVID-19 in the tourism sector. Section 3 describes the methodology, the empirical data and analysis obtained by the research of the 22 companies on the Zagreb Stock Exchange and statistical touristic data in July and August. Finally, section 4 reports the discussion of the obtained results.

\section{Literature review}

The COVID-19 pandemic, after the initial boom in the second quarter of 2020, took over life and business throughout 2020 and continued into 2021. Tourism accounted 10 percent of the GDP, 12 percent of the EU employment, according to the data for 2018, and 19.8 percent in Croatia. According to the EBRD, the tourism revenues exceed one-fifth of the GDP [1] in Croatia, Georgia, Greece, Albania, Montenegro and Cyprus. The higher the tourism share in GDP, the more significant the impact of the tourism sector on the entire economy of a country.

Pandemics have a severe negative impact on economic activities, at least in the short run. Crises, [3] among other things, have to offset and cascading effects (disruption of services, travel and others). Companies in the US have dramatically reduced job vacancies from the 2nd week of March 2020 [4].

Partial or complete lockdown is disastrous for the whole economy and especially for the tourism industry. The increasing number of lockdown days, monetary policy decisions and international travel restrictions imposed at the peak of the coronavirus crisis severely affected the level of general economic activities [5].

In the first months of the Covid-19 pandemic, small tourism businesses were most affected [6].

Decreased income, job loss and the inability to quickly find a new job mark consumption. Each crisis leaves a mark on the number of employees and the possibility of finding a new job, which was confirmed in the [7] survey that about 50 percent of the working population might not find work. Aggregate consumption fell by 9.3 percent over 32 weeks [8].

On the online survey of 500 US consumers find that 28 percent of the respondents in that survey delayed/postponed future travel plans and that 40 percent forewent food purchases [9].

International tourist arrival data from 221 countries/regions from 1995-2018. The results of this study reveal that the network density of international tourist flows is increasing [10].

The tourism industry faces multiple changes (economic crises, climate change, technology innovation). Because of the tourism vulnerability, the paper proposes a holistic model to measure organisational resilience [11].

Innovations are one way out of the crisis $[12,13]$. Innovation reinforces capabilities that positively influence risk management capability [14]. One is to developed a mobile application for tourism. The case study "Calarcheo Park", [15] shown the experience of a real immersion through a journey in virtual reality.

In their study authors [16] present travellers' reactions during the pandemic trends outlined by adopting text mining techniques The Trip Advisor forums had approximately 75,000 travellers' comments between December 30, 2019, to March 15, 2020, and 23,515 cases from the US, Europe, and Asia forums. The results reveal that the tourism sector is easily affected by global crises at the beginning of lockdown in many countries. The countries with a high share of tourism in GDP, like Croatia (20 percent) had a big decreasing of their growth. In the crises time, demand for tourist travel depending on the level of income of tourists' origin countries and the price level in Azerbaijan [17] or some other countries. In Covid-19 crises touristic demand also depends on the epidemiological situation in the countries.

The vast majority of the studies questioned the tourism effects of COVID-19 focus on regional impact analysis. The COVID-19 outbreak has had a devastating effect on the world economy as well as Indonesia's economy [18], especially the travel and tourism sector, which experienced losses of US $\$ 500$ 
million per month. Bintan's tourism [19] sector dominates by foreign tourists from China and other neighbouring countries like Singapore and Malaysia. The decline of tourists, due to the COVID-19 outbreak, has affected businesses related to Bintan's tourism sector, such as hotels, gift shops, and local fishermen. Ischgl, a popular ski town in the Austrian Alps was the first source of COVID-19 pandemic in 2020. Ski town with 492,798 tourists arrived in the 2018/2019 season from over 20 different countries, finished the ski season in 14 March, 2020. [20]. A few countries decided to postpone the reopening of ski areas in 2021, but it not finds evidence to support the association between COVID-19 spread and skiing [21]. The effect of global travel restrictions is an opportunity to reconsider a transformation of the global tourism system [22]. The post-COVID-19 tourism industry need to be more economically equitable, more socially and more environmentally sustainable [23].

Tourism industry depend not only the financial or health crises, but also about of terrorist activities. Many countries participation in all anti-terrorist activities. Azerbaijan [24] takes the 103rd place out of 163 countries in the terrorism index and make a lot of efforts and funds for anti-terrorist activities to support the development of tourism.

In crises or not, a government need to optimize the structure of tourism development [25] and promote the development of a complex ecosystem with smart tourism, global tourism, and ecotourism as the main body to established. development of tourism and poverty alleviation efficiency.

\section{Methodology, empirical data and analysis}

The research covers the pandemic COVID-19 situation in two diverse topics: business results of listed hotels companies in 2020 and tourism as a sector during the peak seasons in two pandemic years.

A sample of all 22 hotel companies' business operations in sector I - Accommodation and food service activities, whose stocks are listed on the Zagreb Stock Exchange used in the research.

All data calculated from the financial statements for the year 2020. Financial data for the current and previous year are in the yearly financial statement. All listed companies are required to apply The International Accounting Standards and the data are comparable. All companies worked with a reduced capacity during the pandemic COVID-19.
Data for peak touristic seasons is collected from the touristic statistic for July and August for 2021, 2020 and 2019.

Multiple regression analysis was used in the paper together with Descriptive Statistics and Correlation. Multiple regression is a statistical technique has used to analyse the relationship between a single dependent variable and several independent variables. The objective of multiple regression analysis is to use the independent variables whose values are known to predict the value of the single dependent value. Each predictor value is weighed, the weights denoting their relative contribution to the overall prediction. Multiple regression analysis uses to find the strongest business indicators that indicate the business results of hotel companies in Croatia during the corona crisis.

The equation of the multiple regression function, in Unstandardised model, takes the following form:

$$
Y=b_{0}+b_{1} x_{1}+b_{2} x_{2}+\ldots .+b_{k} x_{k}
$$

In the multiple regression function $\mathrm{Y}$ is the dependent variable which is calculated to show the business results of touristic companies or the model PROF - the function of predicting business performance. The variable $\mathrm{X} 1, \ldots, \mathrm{Xn}$ are the $\mathrm{n}$ independent variables such as the indicators of liquidity, indebtedness, activities or profitability touristic companies calculating from annual financial reports. In calculating the weights, a, b1,..,bn, regression analysis ensures maximal prediction of the dependent variable from the set of independent variables. The variable b0 present the constant. The constant in the model represents the average value of the dependent variable when all independent variables are equal to zero.

The equation of the multiple regression function, in Standardised model, takes the following form:

$$
Y=b_{1} x_{1}+b_{2} x_{2}+\ldots .+b_{k} x_{k}
$$

In the multiple regression function in Standardised model is the same variable, but without constant. $\mathrm{Y}$ is the dependent variable which is calculated to show the business results of touristic companies or the model PROF - the function of predicting business performance. The variable $\mathrm{X} 1, \ldots, \mathrm{Xn}$ are the $\mathrm{n}$ independent variables such as the indicators of liquidity, indebtedness, activities or profitability touristic companies calculating from annual financial reports. In calculating the weights, a, $b 1, \ldots, b n$, regression analysis ensures maximal prediction of the dependent variable from the set of independent variables. 
Based on the financial statements data for the 22 hotel companies listed on the Zagreb Stock Exchange, the indicators most commonly used to predict business difficulties were used [26], along with the ones used to indicate business excellence [27].

After that, to extract the liquidity, indebtedness, activity and profitability indicators, which best outline the situation in the hotel companies at the time of the corona crisis, given the specifics of the Croatian economy, use the method of analysis and comparison.

The liquidity indicators used in the first indicator calculation are gross working capital, net working capital, the ratio of gross working capital to total assets.

Indebtedness indicators used in the first indicator calculation are net debt /EBITDA, debt to equity ratio, financial ratio and financial strength.

The activity indicators used in the first indicator calculation are the turnover ratio of total assets.

Profitability indicators used in the first indicator calculation are EBIT, EBIT/A, EBITDA, EBITDA/A, ROA, ROE, gross profit margin and net profit margin, gross profit /asset and net profit/asset.

The multiple regression function was used the enter method option, with a critical value for input and output of 0.01 .

All variables were used in creating the model are shown in Table 1.

Table 1: Descriptive Statistics

\begin{tabular}{|c|c|c|c|c|}
\hline \multicolumn{5}{|c|}{ Descriptive } \\
\hline & Aberration & Mean & Std. Deviation & $\mathrm{N}$ \\
\hline PROFIT/LOSS & $\mathrm{P} / \mathrm{L}$ & 1.545 & 0.504 & 44 \\
\hline EBIT & EBIT & $-6,331,690.417$ & $115,868,738.822$ & 44 \\
\hline EBITDA & EBITDA & $67,057,681.742$ & $153,238,698.276$ & 44 \\
\hline $\begin{array}{l}\text { NETO } \\
\text { DEBTS }\end{array}$ & $\mathrm{ND}$ & $367,735,054.335$ & $637,407,701.454$ & 44 \\
\hline ND/EBITDA & ND/EBITDA & -278.929 & 1918.465 & 44 \\
\hline${ }_{S}$ EBIT/ASSET & EBIT/A & 0.000 & 0.125 & 44 \\
\hline EBITDA/A & EBITDA/A & 0.048 & 0.122 & 44 \\
\hline ROA & ROA & -0.003 & 0.123 & 44 \\
\hline ROE & ROE & -0.020 & 0.176 & 44 \\
\hline $\begin{array}{l}\text { GROSS PROFIT } \\
\text { MARGIN }\end{array}$ & GPM & -2.404 & 10.452 & 44 \\
\hline $\begin{array}{l}\text { NET PROFIT } \\
\text { MARGIN }\end{array}$ & NPM & -2.307 & 10.328 & 44 \\
\hline $\begin{array}{l}\text { GROSS } \\
\text { WORKING }\end{array}$ & GWC & $136,045,648.085$ & $211,971,716.485$ & 44 \\
\hline $\begin{array}{l}\text { CAPITAL } \\
\text { NET WORKING } \\
\text { CAPITAL }\end{array}$ & NWC & $14,157,256.676$ & $185,431,632.316$ & 44 \\
\hline $\begin{array}{l}\text { GROSS } \\
\text { WORKING } \\
\text { CAPITAL/ASSE } \\
\mathrm{T}\end{array}$ & GWC & 0.126 & 0.116 & 44 \\
\hline $\begin{array}{l}\text { NET WORKING } \\
\text { CAPITAL/ASSE } \\
\text { T }\end{array}$ & NWC & 0.037 & 0.138 & 44 \\
\hline $\begin{array}{l}\text { GROSS } \\
\text { PROFIT/ASSET }\end{array}$ & GP/A & -0.006 & 0.125 & 44 \\
\hline $\begin{array}{l}\text { TOTAL ASSET } \\
\text { TURNOVER }\end{array}$ & TAT & 0.199 & 0.140 & 44 \\
\hline $\begin{array}{l}\text { FINANCIAL } \\
\text { RATIO }\end{array}$ & FR & 0.577 & 0.382 & 44 \\
\hline $\begin{array}{l}\text { FINANCIAL } \\
\text { STRENGTH }\end{array}$ & FS & 1.923 & 8.753 & 44 \\
\hline
\end{tabular}

Source: Author
Table 2 shows the elements of the first Model summary with all independent variables. The model is statistically significant $\mathrm{p}<0.001$, and all variables explained $80.5 \%$ of the dependent variables result of the financial year $(\mathrm{P} / \mathrm{L})$. In the first model. all independent variables are not significant.

Table 2 Model - 1st step

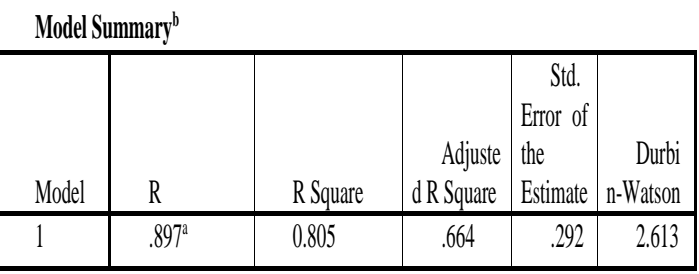

a. Predictors: (Constant). F S. GWC, ND/EBITDA. NPM, EBITDA, FR, GWC/A,

TAT, ND, ROE, NWC, WCN/A, EBIT, EBITDA/A, GP/A, ROA. GPM. EBIT/A

b. Dependent Variable: P/L

\section{Source: Author}

In the second step, the development of the model has included only three statistically significant variables ( $\mathrm{p}<0.001)$, ROE, TAT and FS, connected with dependent variable result of the financial year $(\mathrm{P} / \mathrm{L})$.

In table 3 shows the correlation of statistically significant independent variables. Person Correlation coefficient shows that the independent variables are related to the dependent variable with a negative sign; decreasing one variable increases the other variable, ROE $(\mathrm{r} 1=-0.619)$. TAT $(\mathrm{r} 2=-0.751)$ i FS ( $\mathrm{r} 3=-$ 0.344 ). According to the correlation coefficient ( $\mathrm{r}$ $<0.8$ ) is evident that no multicollinearity is present.

Table 3: Correlations

Correlations

\begin{tabular}{|cl|l|l|l|l|}
\hline & & P/L & ROE & TAT & FS \\
\hline Pearson & P/L & 1.000 & -.619 & -.751 & -.344 \\
Correlation & ROE & -.619 & 1.000 & .605 & .710 \\
& TAT & -.751 & .605 & 1.000 & .495 \\
& FS & -.344 & .710 & .495 & 1.000 \\
Sig. (1-tailed) & P/L & & .000 & .000 & .011 \\
& ROE & .000 & & .000 & .000 \\
& TAT & .000 & .000 & & .000 \\
& FS & .011 & .000 & .000 & \\
N & P/L & 44 & 44 & 44 & 44 \\
& ROE & 44 & 44 & 44 & 44 \\
& TAT & 44 & 44 & 44 & 44 \\
& FS & 44 & 44 & 44 & 44 \\
\hline
\end{tabular}

Source: Author 
The model PROF - the function of predicting business performance used the three independent variables ROE, TAT and FS. The independent variables are explained in Table 4.

Table 4: Formulas for calculating the PROF ratio

\begin{tabular}{|c|c|c|}
\hline Description & Counter & Denominator \\
\hline $\begin{array}{l}X_{1}=\text { PROFITABLITIES - } \\
\text { ROE }\end{array}$ & NETPROFIT(NP) & EQUTTY (E) \\
\hline $\begin{array}{l}X_{2}=\text { ACTIVITY INDICATOR- } \\
\text { TOTAL ASSETS TURNOVER } \\
\text { RATIO(TAT) }\end{array}$ & BUSINESS REVENUE(BR) & ASSETS (A) \\
\hline X3= FINANCIAL STRENGTH & $\begin{array}{cc}5 *(\text { (NET } & \text { PROFIT }+ \\
\text { DEPRECIATION }+ & \\
\text { AMORTIZATION) } & \end{array}$ & TOTALDEBT \\
\hline
\end{tabular}

Source: Author

In table 5 shows a model PROF summary. Selected independent variables, ROE, TAT and FS explain 64.3\% PROF models of the dependent variable P / L. The result of the Durbin-Watson test should have a value of about 2 . The model has a value of 2,048 that indicates the absence of autocorrelation, or it says that the residual deviations are not correlated.

Table 5. Model PROF Summary

Model Summary ${ }^{\mathrm{b}}$

\begin{tabular}{|c|c|c|c|c|c|}
\hline del ${ }_{\text {do }}$ & $\mathrm{R}$ & $\begin{array}{c}\mathrm{R} \\
\text { Square }\end{array}$ & $\begin{array}{ll}\text { Adjusted } & R \\
\text { Square } & \\
\end{array}$ & $\begin{array}{l}\text { Std. Error of the } \\
\text { Estimate }\end{array}$ & $\begin{array}{l}\text { Durbin- } \\
\text { Watson }\end{array}$ \\
\hline 1 & .802 & .643 & .616 & .312 & 2.048 \\
\hline
\end{tabular}

a. Predictors: (Constant). FS, TAT, ROE

b. Dependent Variable: P/L

\section{Source: Author}

Table 6 shows the ANOVA Test of Model PROF. The results of the ANOVA with F-ratio indicate a statistically significant contribution of the independent variable in the explanation of the dependent variable. ANOVA provides an answer if the tested regression model explains a statistically significant proportion of variance. When the p-value of the F-ratio is greater than 0.05 , it is concluded that the independent variables do not predict the dependent variable statistically significantly. When the $\mathrm{p}$ value of the F-ratio is less than 0.05 , it is concluded that the independent variable statistically significantly predicts the dependent variable, ie that the regression model statistically significantly predicts the variance of the dependent variable. The F-ratio tests the statistical significance of the coefficient of determination or explains to what extent the statistically significant influence of determining independent variables on the dependent variable is. The value of F-ratio refers to the complete model. In the PROF model is a statistically significant contribution of the variation of the independent variables ROE, TAT and FS in the explanation of the dependent variable result of business performance touristic companies $(\mathrm{F} 3,40=$ 23.977, $\mathrm{p}<0.001$ ). According to the result it can conclude that the regression model PROF in the whole statistically significantly predicts the business performance. In multiple regression analysis, the statistical F-ratio does not necessarily mean that all variables contribute statistically significantly to the explanation of the variance of the regression model.

Table 6. ANOVA ANOVAa

\begin{tabular}{|c|c|c|c|c|c|}
\hline Model & $\begin{array}{l}\text { Sum of } \\
\text { Squares }\end{array}$ & df & $\begin{array}{l}\text { Mean } \\
\text { Square }\end{array}$ & $\mathrm{F}$ & Sig. \\
\hline Regression & 7.011 & 3 & 2.337 & 23.977 & $.000^{6}$ \\
\hline Residual & 3.899 & 40 & .097. & & \\
\hline Total & 10.909 & 43 & & & \\
\hline
\end{tabular}

Source: Author

The statistically significant contribution of an individual variable to the regression model is estimated by the table 7 Coefficients of the regression model. Table 7 lists the model values in Unstandardised Coefficients and Standardised Coefficients as well as the tolerance coefficient and VIF. The value of the Variance Inflation Factor (VIF) determines the hidden relationships between the variables. The assumption of collinearity of independent variables is violated if the VIF is greater than 10. In the model, the VIF is about 2 and therefore the assumption of multicollinearity is not violated. The tolerance index is needed to be greater than 0.2. In the model, the tolerance is more than 0.4 , which confirms that the assumption of collinearity of independent variables is not violated. Standardised coefficients are used in the model to ensure the comparability of the variables of the multiple regression model. The standardised beta regression coefficient indicates the contribution of an individual variables to the regression model. The t-test indicator calculates, which individually tests the statistical significance of the contribution of each independent variable to the regression model. 
Table 7. MODEL PROF

\begin{tabular}{|c|c|c|c|c|c|c|c|}
\hline \multirow[b]{2}{*}{ Model } & \multicolumn{2}{|c|}{$\begin{array}{l}\text { Unstandardisised } \\
\text { Coefficients }\end{array}$} & \multirow{2}{*}{$\begin{array}{l}\text { Standard. } \\
\text { Coeff. } \\
\text { Beta }\end{array}$} & \multirow[b]{2}{*}{$t$} & \multirow[b]{2}{*}{ Sig. } & \multicolumn{2}{|c|}{$\begin{array}{l}\text { Collinearity } \\
\text { Statisics }\end{array}$} \\
\hline & B & $\begin{array}{r}\text { Std. } \\
\text { Error }\end{array}$ & & & & \begin{tabular}{|l} 
Toleran \\
ce
\end{tabular} & VIF \\
\hline (Constant) & 1.933 & .101 & & 19.103 & .000 & & \\
\hline ROE & -1.246 & .422 & -436 & $-2,955$ & .005. & .410. & 2.438 \\
\hline TAT & -2.231 & .429 & -.622 & -5.2003 & .000 & .625 & 1.600 \\
\hline FS & .016 & .008 & .273 & 2020 & .050 & .489 & 2.046 \\
\hline
\end{tabular}

a. Dependent Variable: P/L

Source: Author

According to the results of multiple regression analysis, p-value for all regression coefficients is less than or equal to 0.05 . The null hypothesis according to which the regression coefficients are equal to zero (0) is rejected, that is, it is confirmed that the contribution of each independent variable is statistically significant in the multiple regression model.

The function in a standardized form is: $\mathrm{PROF}=(-0.436) \times 1+(-0.622) \times 2+0.273 \times 3$

$\mathrm{PROF}=(-0.436) \mathrm{ROE}+(-0.622) \mathrm{TAT}+0.273 \mathrm{FS}$ (3)

Predictive ability of independent variables ROE, TAT and FS are justified because all non-basic variables contribute statistically significantly to the model. In table 7 , in addition to the values of individual coefficients of independent variables, the t-test indicator is also calculated. T-test, individually tests the statistical significance of the contribution of each an independent variable in the PROF model.

The first variable in the model is ROE. ROE has the statistically significant predictive power in explanation of result of business performance touristic companies $(\mathrm{b} 1=-0.422, \mathrm{t}=-2.955, \mathrm{p} \leq$ 0.005). The second element in the model is total assets turnover ratio. TAT has the statistically significant predictive power in explanation of result of business performance touristic companies (b2 = $0.626, \mathrm{t}=-5.203, \mathrm{p}<0.001)$. The third element in PROF formula is financial strength. FS has the predictive power in explanation of result of business performance touristic companies $(\mathrm{b} 3=0.273 . \mathrm{t}=$ $2.020, \mathrm{p} \leq 0.050$ ).

Each unit increase in the value of the ROE ratio reduces the value of the $\mathrm{P} / \mathrm{L}$ operating result by
0.436, provided that the other variables remain unchanged. Each unit increase in the value of the TAT coefficient reduces the value of the $\mathrm{P} / \mathrm{L}$ operating result by 0.626 , provided that the other variables remain unchanged. Each unit increase in the value of the FS coefficient increases the value of the $\mathrm{P} / \mathrm{L}$ operating result by 0.273 , provided that the other variables remain unchanged.

The obtained PROF coefficient can be ranked in more detail in the following groups:

PROF <0. i.e., negative - the company is facing difficulties, the higher negative result indicates that the company is facing serious business difficulties that may lead to bankruptcy

$\mathrm{PROF}=0 \leq 1$ - the company is in the grey zone

PROF> 1. i.e., positive - the company is doing well, the higher the positive result, the higher the liquidity and profitability of the company and the more secure the company are in its future.

In graph 1 is shown the arrivals and night index in July and August in 2021, 2020 and 2019. In a peak season, 2021 was 55.65 percent more arrivals and 40.32 percent more nights according to 2020 , and 84.44 percent arrivals and percent nights of 2019 , a year before COVID-19. Domestic guests (96.41 percent of overnight stays compared to 2019) contributed the results. In 2020, it was 54.24 percent arrival and 62.62 percent of nights of 2019.

Graph 1. Arrivals and nights in July and August index 2021,2020, 2019

\section{ARRIVALS AND NIGHTS IN JULY AND AUGUST 2021, 2020 AND} 2019

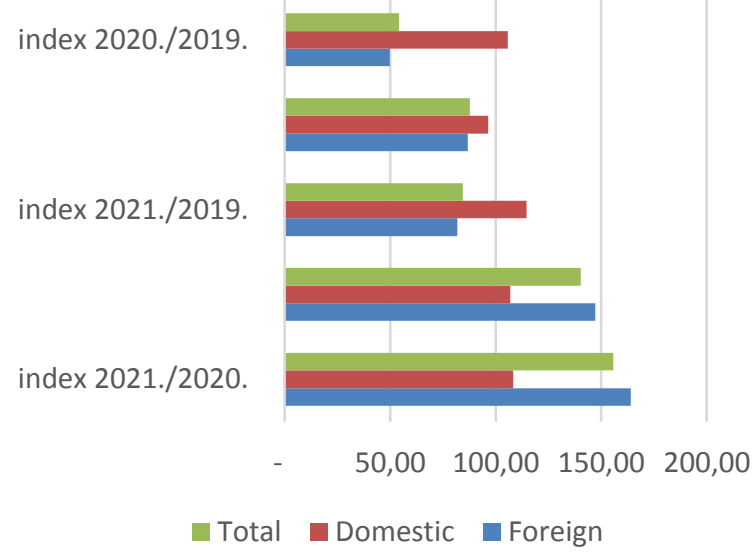

Sources: Author according to [23]. 


\section{Discussion}

In Croatia, the main feature of tourism is the seasonality, i.e., the duration of the tourist season on the Adriatic from June to September. The main tourist season is in July and August, and June and September belong to the pre-season and sub-season. Foreign tourists realise the majority of overnight stays and arrivals in Croatia. Mediterranean countries are Croatia's main competitors. The most significant competitors are Malta and Cyprus.

The recovery of physical indicators began in midJune 2020. It intensified until the end of August, when with the deteriorating epidemiological situation in Croatia, many countries decided to significantly tighten the travel conditions of their citizens to Croatia, including Austria, Slovenia and Germany. As a result, in 2020, the five main markets (Germany, Slovenia, Poland, the Czech Republic and Austria) accounted for almost three-quarters of the total number of overnight stays, an increase of more than 20 percentage points compared to the same period the year before.

The pandemic had a strong and negative impact on tourism in 2020. As a result, the structure of Croatian tourism has changed, with a significant increase in the concentration of the emitting markets for which Croatia is predominantly a road destination, while a further decrease in the share of tourists from countries from which they mainly arrive by plane.

The dynamics of tourism activity differed significantly at the regional level. Counties in which guests from road destinations dominate the structure stood out with the lowest rates of decline in tourist activity of foreign guests. This is especially true in the Istria and Zadar counties, where the recovery began significantly in mid-June 2020 . They were later joined by the Split-Dalmatia and Šibenik-Knin counties, where a more intensive recovery began in mid-July. The worst results of all Adriatic counties during the entire season are Dubrovnik-Neretva, i.e., the city of Dubrovnik, which usually records a significant number of arrivals by air.

The dynamics of tourism activity at the regional level are shown in table 8. Domestic tourists saved the 2020 season. In July and August 2020, overnight stays in the Adriatic region were 63 percent compared to the 2019 season, with 91 percent domestic guests and only 59 percent foreign guests. The peak Adriatic season 2021 was 40 percent better than 2019, 64 percent better in Dubrovnik-Neretva countries and 54 percent more in Istria.
Table 8. Nights of registered tourists for the period July to August 2021/2020/2019 by counties (all capacities)

\begin{tabular}{|c|c|c|c|c|c|c|c|c|c|}
\hline \multirow[b]{2}{*}{ Counties } & \multicolumn{3}{|c|}{ index 2021/2020 } & \multicolumn{3}{|c|}{ index 2021/2019 } & \multicolumn{3}{|c|}{ index 2020/2019 } \\
\hline & DG & FG & Total & DG & FG & Total & DG & FG & Tota \\
\hline Istria & 116 & 155 & 154 & 103 & 91 & 154 & 89 & 59 & 60 \\
\hline Kvarner & 102 & 134 & 128 & 87 & 87 & 128 & 85 & 65 & 68 \\
\hline Lika-Senj & 96 & 144 & 135 & 84 & 85 & 135 & 87 & 59 & 63 \\
\hline Zadarska & 109 & 132 & 124 & 95 & 89 & 124 & 87 & 67 & 73 \\
\hline $\begin{array}{l}\text { Šbenik- } \\
\text { Knin }\end{array}$ & 107 & 142 & 133 & 90 & 86 & 133 & 84 & 60 & 65 \\
\hline $\begin{array}{l}\text { Split- } \\
\text { Dalmatia }\end{array}$ & 107 & 151 & 145 & 118 & 85 & 145 & 110 & 56 & 60 \\
\hline $\begin{array}{l}\text { Dubrovnik- } \\
\text { Neretv. }\end{array}$ & 101 & 176 & 164 & 135 & 75 & 164 & 134 & 42 & 47 \\
\hline $\begin{array}{l}\text { TOTAL } \\
\text { Dalmatia }\end{array}$ & 107 & 146 & 137 & 100 & 84 & 137 & 93 & 58 & 63 \\
\hline $\begin{array}{l}\text { T0TAL } \\
\text { Adriatic }\end{array}$ & 106 & 146 & 140 & 96 & 87 & 140 & 91 & 59 & 63 \\
\hline
\end{tabular}

Sources: Author according [23]

Tightening epidemiological measures makes potential travelers more cautious. More and more tourists have changed their habits to preserve their health. They have opted for other possibilities like family accommodation facilities, camps or nautical tourism (Graph 2). Most of the tourists try to avoid hotel accommodation. In the main tourist season months, the smallest decline was in tourist resorts, camps, and private accommodation. The most significant decline was in hotels and hostels.

Graph 2. The tourist nights in July and August 2021, 2020 and 2019

\section{THE TOURIST NIGHTS IN JULY AND AUGUST}

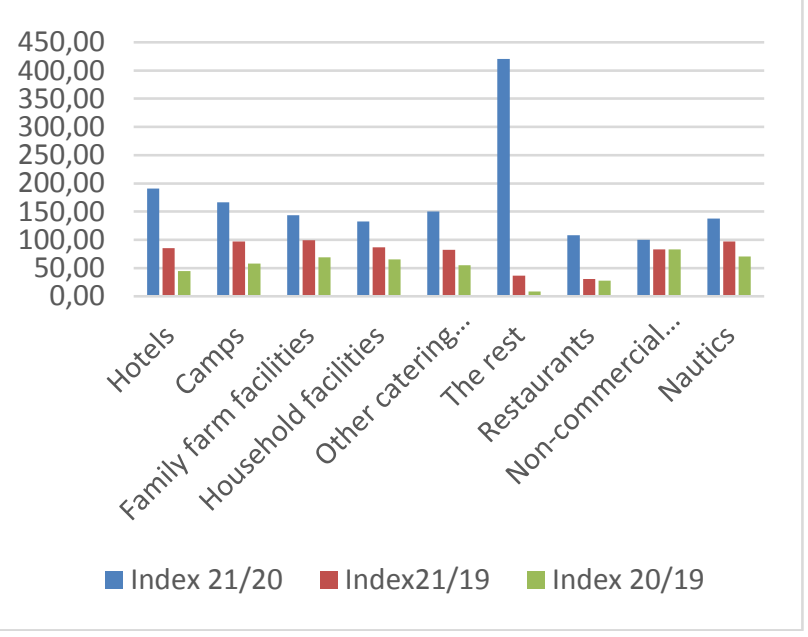

Sources: Author according to [23] 
The Croatian economy recovery from the financial crises 2008/09 only in the fourth quarter of 2014, and reached pre crisis levels only in 2019 (Graph 3). Data show that the pandemic has largely led to a slowdown in the Croatian economy since mid-March 2020. GDP was $2.9 \%$ in 2019 but $-8.0 \%$ in 2020. In 2020, the estimate shows that the quarterly GDP in real terms for Q1 increased 0.2 percent according, but for Q2 decreased by 15.4 percent, for Q3 decreasing 10 percent and for Q4 decreasing 7 percent, as compared to the same quarter of 2019. In 2020 Croatia recorded one of the highest rates of Gross domestic products (GDP) decline by 8 percent in Europe due to the fact that tourism is about 20 percent of GDP. The economic activity in the first quarter of 2021 shows a slowdown in the real GDP decline by 0.7 percent, while in the second quarter of 2021, realised significant growth of $16.1 \%$ compared to the same period of the previous year. Economic growth in Q2 2021 is owing to the growth of all GDP components, mostly personal consumption as its biggest component. like household spending in Q2 grew by 18.4 percent from Q2 2020, after going down by 0.3 percent in Q1. The export of goods and services rose by 40.9 percent, owing to the significant recovery of tourism-related services.

Graph 3. Gross domestic product in Croatia

" GDP (real growth rates)

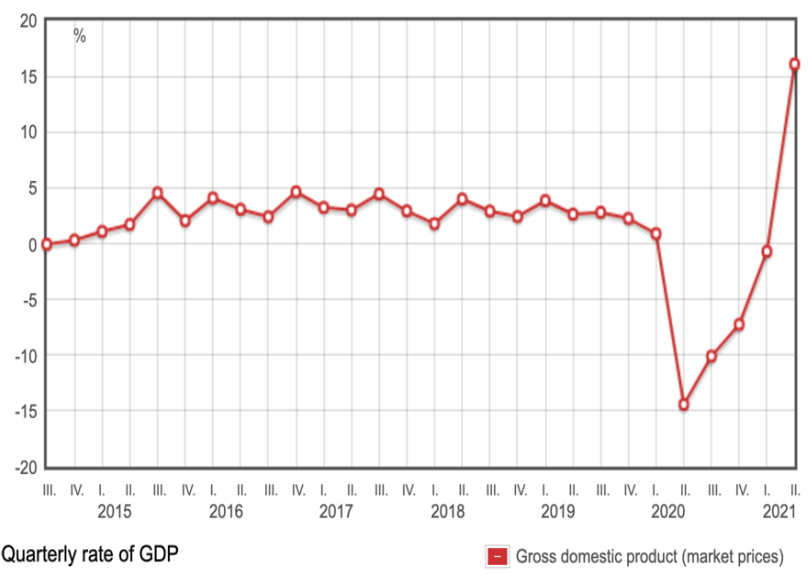

Quarterly rate of GDP

- Gross domestic product (market prices)

Source: [29]

In 2021 as a whole, the real GDP (Hrvatska Narodna Banka, 2021) could increase by $6.8 \%$, which is a quantification that primarily reflects the expectation of a strong recovery in tourism requirements after the decline in the previous year caused by the coronavirus pandemic. A relationship of tourism development and economic growth is very important issue for many countries [28] investigate the relationship using a quantile mediation analysis in Taiwan from 1990 to 2018 . They found a exitance of direct and indirect effect from tourism development to economic growth. From those results, they "suggest that Taiwan's government should focus on the export growth if the government wants to promote Taiwan's economic growth when the economy is in a recession, not focus on tourism development ".

Difficulties caused by coronavirus have led to price increases in almost all sectors. As a result, average annual consumer price inflation [29] could accelerate to $1.7 \%$ in 2021 (from $0.1 \%$ in 2020) and then slow slightly to around $1.5 \%$ in 2022 .

In August 2021, compared to August 2020, that is, at the annual level, the prices of goods and services for personal consumption increased by $3.1 \%$ on average, as shown in graph 4 . Observed by the main groups of the ECOICOP classification the highest increase at the annual level [29] (August 2021 compared to August 2020) was recorded in the prices in the group Transport, of $9.9 \%$ on average (the largest contribution to the index increase of $1.32 \%$ ), followed by the increase in the group Alcoholic beverages and tobacco, of $5.5 \%$ (contribution to the index increase of $0.29 \%$ ), Restaurants and hotels, of $4.4 \%$ (contribution to the index increase of $0.16 \%$ ), Food and non-alcoholic beverages, of $2.4 \%$ (contribution to the index increase of $0.65 \%$ ) and so on.

\section{Graph 4. Inflation in Croatia}

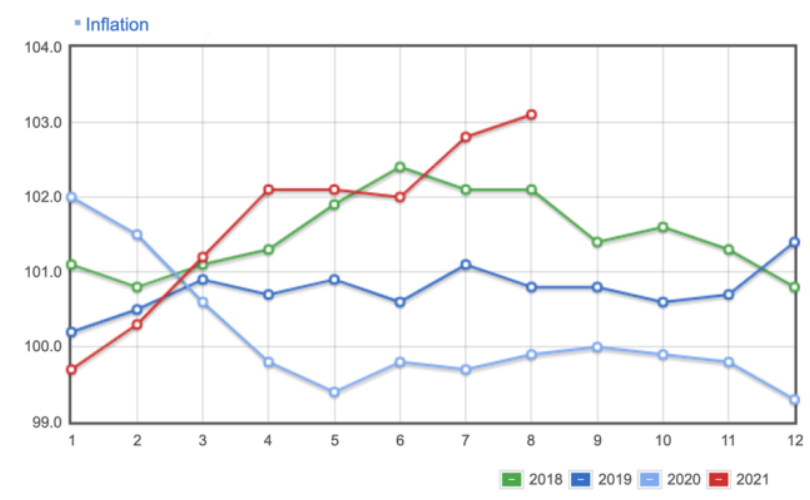

Source: [29]

During the peak tourist season 2021, Croatia has been on the green or orange region on the European Centre for Disease Prevention and Control map, as shown in picture 1. In the last week of August, the Adriatic region and after that in September the rest of Croatia added to the list of "red" regions, but thanks to the standardization of travel processes within the EU, tourist flows continue. 
Picture 1. Weekly-maps-coordinated-restrictionfree-movement

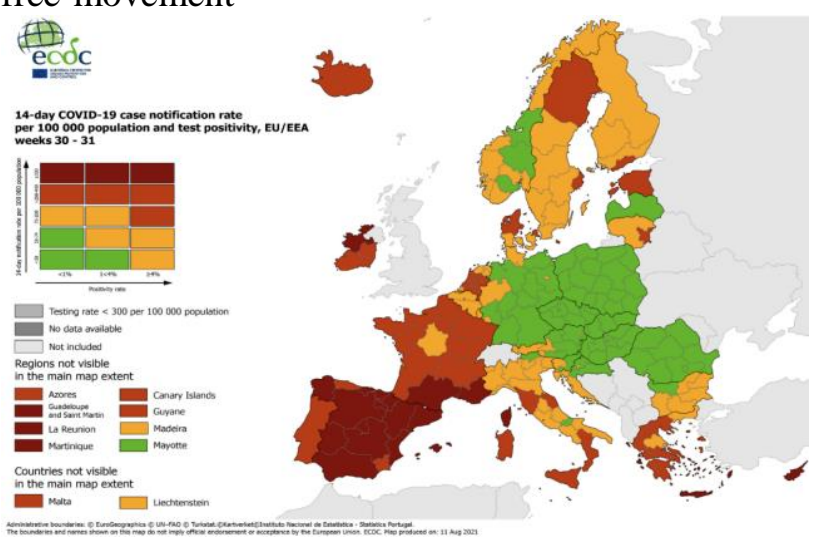

Source: [31]

The great tourist results in July and August 2021 were due to Croatia's good epidemiological situation compared to competing countries, the vaccination of guests and hosts, government support measures, and good road connections.

Table 9 shows some of the listed companies' results, such as business revenue, profit or loss, government support, and PROF ratio for 2020 and 2019. Revenue from business operation in 2020 was only $37 \%$ of 2019 . As a result, all listed group of hotels companies 2020 finished in loss, excepted one, for the differences in 2019 where only three companies had a loss and all others finished the year in profit.

Table 9. Basic results of listed companies in 2020 and 2019

\begin{tabular}{|l|c|c|}
\hline & 2019 & 2020 \\
\hline B. REVENUE & $8,134,173,499$ & $3,016,597,785$ \\
N. RESULT & $1,185,176,190$ & $-1,476,892,541$ \\
G. SUPPORT & & $1,117,111,107$ \\
PROF ratio & 1.05 & -0.23 \\
\hline
\end{tabular}

Source: Author

The average PROF coefficient for 2020 was -0.23 and in 2019 was 1.05. Thus, almost all individual indicators in PROF formula show a deterioration in 2020 compared to the previous period.

The listed hotel companies realized most revenue during the peak touristic season in July and August 2020. However, July and August are the peaks of each tourist season on the Adriatic, i.e., Croatia, in all years, were the good and bad ones.

The first hypothesis: " The corona crisis has caused the deterioration of the business of listed hotel companies almost to the point of closing companies in 2020 " is confirmed.
Since the start of the lockdown, the Government has adopted packages of support measures to preserve jobs and overcome the short-term liquidity problem of entrepreneurs. Some of Government measures are:1) salary for the preservation of jobs in the sectors affected by a coronavirus (HRK 3.250 per employee for salaries in March. or HRK 4.000) and exemption and deferral of tax liabilities, 2) reduction and deferral of payment of fees for the use of concessions on tourist land 3) quarterly deferral of tourist dues and 4) introduction of a moratorium on credit obligations for clients with existing placements.

In October 2020, the Government implemented a new measure are carried out until the CORONA crises continue. A new scale for granting aid has been introduced, especially for the measure of preserving jobs. The measure of support for worker wages continues for the most vulnerable sectors: 1) HRK 2.000 per worker for a turnover drop of at least 40 percent, 2) HRK 2.500 for a turnover drop of 45-50 percent, 3) HRK 3.000 for a drop of 50-55 percent, 4) HRK 3.500 for 55-60 percent, 5) HRK 4.000 per worker for a drop in turnover of 60 percent and more. Beneficiaries of current support measures for microentrepreneurs (1-9 employees) receive support regardless of the sector. The second measure refers to the support of HRK 2.800 (so far HRK 2.000) for shortening the working hours to 70 percent (so far 50 percent). The government's main condition for the support measures is that there are no layoffs from employers.

All surveyed hotel companies that met the conditions used all of the offered measures to minimise the corona crisis's negative effects on business in 2020 and 2021.

Table 10. Correlations

Correlations

\begin{tabular}{|ll|r|r|r|}
\hline & & B. REVENUE 20 & N. RESULT 20 & G. SUPPORT 20 \\
\hline B. REVENUE 20 & Pearson & 1 & $-.752^{* *}$ & .420 \\
& Correlation & & & \\
& Sig. (2-tailed) & & .000 & .052 \\
& $\mathrm{~N}$ & 22 & 22 & 22 \\
N. RESULT 20 & Pearson & $-.752^{* *}$ & 1 & -.066 \\
& Correlation & & & \\
& Sig. (2-tailed) & .000 & & .771 \\
& $\mathrm{~N}$ & 22 & 22 & 22 \\
G. SUPPORT 20 & Pearson & .420 & -.066 & 1 \\
& Correlation & & & \\
& Sig. (2-tailed) & .052 & .771 & 22 \\
\hline & $\mathrm{N}$ & 22 & 22 & \\
\hline
\end{tabular}

**. Correlation is significant at the 0.01 level (2-tailed).

Source: Author 
In table 10 shows the correlation between business revenue, net result and government support. Statistically significant correlation $\mathrm{p}<0.001$ is visible between business revenue and net result. Statistically significant correlation $p<0.05$ is visible between business revenue and government support. The second hypothesis: "There is a statistically significant correlation between the government support in corona crises and financial results" is partially confirmed. In 2020, the financial loss of hotel listed companies was 1,4 million, and total revenue was only 37 percent of 2019 total revenue. The government support of hotel listed companies was 37 percent of total revenue in 2020. The financial result without government support can show a 76 percent bigger loss.

In table 11 is shown the correlation between the arrivals (foreign, domestic and total foreign, domestic and total), night (foreign, domestic and total), GDP, Inflation ECDC zone and competition countries zone. It found a statistically significant correlation between total arrivals and foreign arrivals and foreign night and total night. Therefore, hypothesis H3: "There is a statistically significant correlation between the number of tourists in arrivals and nights, GPF, Inflation and ECDC Zone" is only partially confirmed.

Table 11. Correlation

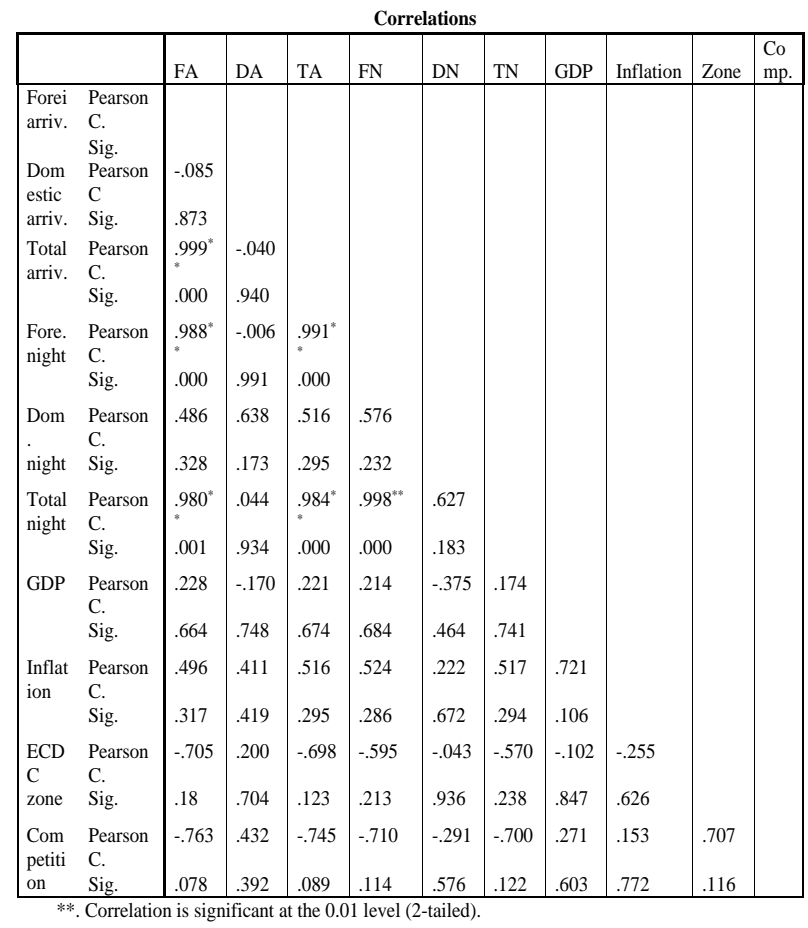

\section{Source: Author}

Spring and summer are the most popular seasons for Europe's tourism industry. In 2019, [32] the spring and the peak summer season each accounted for nearly one-third (32 percent) of the annual total overnight stays. Across the EU Member States, the share that the spring season contributes towards annual tourism accommodation stays is relatively similar, ranging from 24 percent in Croatia and 27 percent in Bulgaria to 35 percent in Cyprus, Luxembourg, Malta and the Netherlands. However, this share went from $23 \%$ in Malta to $58 \%$ for the peak summer season in Croatia. Because of such constraints, the tourism industry alone has lost more than $\$ 200$ billion globally [5]. Furthermore, the policy of "staying at home" and "social distancing" has led to the closure of hotels and restaurants worldwide, the cancellation of sporting events, even the Tokyo Olympics 2020, resulting in enormous losses in all activity segments.

Hotel companies in Croatia began to realize their potential after the crisis in 2008. The touristic companies listed on the Zagreb Stock Exchange achieved better liquidity and solvency in 2017 than in 2012 and 2008 [33].

The listed hotel companies in 2020, achieved only 37 percent of total revenue of 2019. The PROF ratio shows that hotels listed companies that survive corona crises need to improve their financial strength, ROE and total assets turnover.

Due to the consequences of special circumstances caused by the COVID-19 pandemic, all hotel listed companies have a negative result, except one, and the PROF ratio pointed out serious problems with profitability, economic activities and financial straight. If this pandemic continues into next year, the survival of hotel companies will be called into question.

The tourism sector needs to find the adequate territorial strategy or a new way to extend the season or save the tourism in crises. Like in Croatia, Azores also need an adequate territorial planning [34], due to the need to protect the Region's competitive advantages -i.e., natural assets and high levels of sustainability.

\section{Conclusion}

The spread of the COVID-19 epidemic has significantly affected the global economy and, particularly, the achievement of good business results in tourism. The economic crisis caused by the pandemic will affect emerging markets and emerging economies over several quarters due to the pressure on the weak health systems, loss of trade and tourism, slow remittances, reduced capital flows and tighter financial conditions due to the rising debt [35].

According to the optimistic forecast recovery of up to 85 percent of 2019 volumes by 2021 and full recovery by 2023 is expected [36]. However, under 
a pessimistic recovery scenario, 2021 levels can be as low as 60 percent of 2019, further postponing the recovery.

In Croatia for 2022 [30], it is assumed that revenues from tourism could reach 66 percent of the 2019 level in the stressful, 74 percent in the pessimistic, 88 percent in the basic and 94 percent in the optimistic scenario. Only in 2023 could revenues from tourism exceed the record 2019 in the optimistic scenario, and in 2024 the same could happen according to the baseline scenario.

The limitations of this research are the small number of hotel houses listed on the Zagreb Stock Exchange, as well as the fact that it is known as the only result of the year 2020. Moreover, in the Adriatic region, the peak touristic season is abridged, only in July and August, which is not a good result for touristic companies.

A corona crisis, that is spreading rapidly and affecting life and the economy, will be the subject of research for a long time to come. Any information on health and economic impacts on individual life and activity is significant for future research. The crisis has shown that it is necessary to develop new ways of tourism development using all the advantages of modern technology. The stage of application of new technologies in the development of tourism in Croatia is the subject of further research.

Drakopoulos [38] compared the world tourism recovery period after the three previous crises, relying on UNWTO data. Tourism recovered the fastest after the SARS epidemic in 2003, - it took 5 months. The recovery after the attack on the WTO twins in New York on September 11, 2001, took 6 months, and it took 10 months for tourism to recover from the onset of the global economic crisis in 2009. The question of how long the recovery from the crisis caused by the COVID-19 response will take depends largely on vaccinating the most significant part of the world population and stopping the pandemic. Only when the pandemic is stopped can measures be taken to help recover tourism and the entire economy. The speed of the recovery of certain sectors of the economy, especially tourism, and the measures taken, are the subject of new future research. In the National recovery and resilience plan, [38] pointed out the main challenges in the Croatian tourism sector and areas for improvement.

In COVID-19 pandemic, the role of government support is very important, but cannot replace the good touristic season. Both, hotel companies and the governments need to be particularly innovative to save tourism. The governments of all tourist destinations and in Croatia must adopt new measures to maintain the tourism sector and prepare for the new tourist season next year.

\section{References:}

[1] World Tourism Organization (UNWTO) (2020). Covid-19 response: $96 \%$ of global destinations impose travel restrictions, UNWTO reports. Available at: https://www.unwto.org/news/covid-19response-travel-restrictions

[2] Državni zavod za statistiku (2020). Tourist arrivals and nights in commercial accommodation establishments. Available at: https://www.dzs.hr/Eng/Covid-19/tourismarrivals_and_nights_2020.html

[3] Jonas, O. B. (2013). Pandemic Risk World Development Report 2014 on Risk and Opportunity: Managing Risks for Development. Available at: https://openknowledge.worldbank.org/bitstrea m/handle/10986/16343/WDR14_bp_Pandemic _Risk_Jonas.pdf?sequence $=1$ \&isAllowed $=\mathrm{y}$

[4] Kahn, L. B., Lange. F., Wiczer, D. G. (2020). Labour Demand in the Time of COVID-19: Evidence from Vacancy Postings and UI Claims (Working Paper No. 27061; Working Paper Series). National Bureau of Economic Research. Available at: https://doi.org/10.3386/w27061

[5] Ozili, P., Arun, T. (2020). Spillover of COVID-19: impact on the Global Economy. Electronic Journal. Available at: https://doi.org/10.2139/ssrn.3562570

[6] Zupan Korže, S., Škabar, M. (2020). Covid19 footprint to tourism and small tourism businesses in the first period of pandemic. Advances in Business-Related Scientific Research Journal 11(2). GEA College - Faculty of Entrepreneurship. Ljubljana. 90-111. Available at: https://www.absrc.org/publications/absrj-2020volume-11-number-2/

[7] Gourinchas, P.O. (2020). Flattening the pandemic and recession curves. Mitigating the COVID Economic Crisis: Act Fast and Do Whatever. Available at: http://vietstudies.net/kinhte/COVIDEconomicCrisis.pdf\# page $=38$

[8] Eichenbaum, M. S., Rebelo. S., Trabandt, M. (2020). The Macroeconomics of Epidemics (Working Paper No. 26882; Working Paper 
Series). National Bureau of Economic Research. Available at: https://doi.org/10.3386/w26882

[9] Binder, C. (2020). Coronavirus Fears and Macroeconomic Expectations. Social Sciences Research Network. 34. Available at https://doi.org/10.2139/ssrn.3550858

[10] Shao, Y., Huang. SS., Wang. Y., Li Z., Luo. M. (2020). Evolution of international tourist flows from 1995 to 2018: A network analysis perspective. Tourism Management Perspectives. Vol.36 Available at: https://doi.org/10.1016/j.tmp.2020.100752.

[11] Melian-Alzola, L., Fernandez-Monroy, M., Hidalgo-Penate, M. (2020). Hotels in contexts of uncertainty: Measuring organisational resilience. Tourism Management Perspectives. Vol. 36. Available https://doi.org/10.1016/j.tmp.2020.100747

[12] Morais-Storz, M., Platou, R. S., Norheim, K. B. (2018). Innovation and metamorphosis towards strategic resilience. International Journal of Entrepreneurial Behavior and Research. 24(7). 1181-1199. Available at: https://doi.org/10.1108/IJEBR-11-2016-0369

[13] Rahi, K. (2019). Indicators to assess organizational resilience-a review of empirical literature. International Journal of Disaster Resilience in the Built Environment. 10(2/3). 8598. Available at: https://doi.org/10.1108/IJDRBE-11-2018-0046

[14] Sabahi, S., Parast, M. M. (2020). Firm innovation and supply chain resilience: A dynamic capability perspective. International Journal of Logistics Research and Applications. 23(3). 254-269. Available at: https://doi.org/10.1080/13675567.2019.1683522

[15] Barrile, V., Fotia, A., Bernardo, E., Candela, G., (2020). Geomatics Techniques for Submerged Heritage: A Mobile App for Tourism. WSEAS Transactions on Environment and Development $16 . \quad 586-597$. https://doi.org/10.37394/232015.2020.16.60

[16] Güliz Uğur, N., Akbıyı, A. (2020). Impacts of COVID-19 on global tourism industry: A cross-regional comparison. Tourism Management Perspectives. Vol. 36. Available at: https://doi.org/10.1016/j.tmp.2020.100744

[17] Mayis, G.G., Shafa, G.T., Leyla, H.A, Hijran, M.R., Ulker, M.I., (2021). Estimation of Tourism Demand and Supply Functions for Azerbaijan: 2SLS Approach, WSEAS Transactions on Business and Economics. 18, 1280-1290,

https://doi.org/10.37394/23207.2021.18.119
[18] Dinarto, D., Wanto, A., Sebastian, L. C. (2020). Global health security-COVID-19: Impact on Bintan's tourism sector. RSIS Commentaries. 33.

[19] Correa-Martínez, C. L., Kampmeier, S., Kümpers, P., Schwierzeck, V., Hennies, M., Hafezi, W., Kühn, J., Pavenstädt, H., Ludwig, S., Mellmann, A. (2020). A pandemic in times of global tourism: Superspreading and exportation of COVID-19 cases from a ski area in Austria. Journal of Clinical Microbiology. 58(6). 1-3. Available

at: https://doi.org/10.1128/JCM.00588-20

[20] Gianfredi, V., Mauer, N.S., Gentile, L., Riccò, M., Odone, A., Signorelli, C. (2021) COVID-19 and Recreational Skiing: Results of a Rapid Systematic Review and Possible Preventive Measures. Int. J. Environ. Res. Public Health 18, 4349. Available at https://doi.org/10.3390/ ijerph18084349

[21] Gössling, S., Scott. D., Hall, C. M. (2021). Pandemics, tourism and global change: A rapid assessment of COVID-19. Journal of Sustainable Tourism. 29(1), 1-20, Available at: https://doi.org/10.1080/09669582.2020.1758708

[22] Niewiadomski, P. (2020). COVID-19: From temporary de-globalisation to a re-discovery of tourism? Tourism Geographies. 22(3), 651-656. Available

at: https://doi.org/10.1080/14616688.2020.1757749

[23] Hrvatska turistička zajednica (HTZ) (2021). Informacije o statističkim pokazatelja prometa, Available at: https://www.htz.hr

[24] Aliyev, V., (2020). The Role of the Struggle against Terrorism in Tourism Development in Azerbaijan, WSEAS Transactions on Environment and Development 16. 464-470. https://doi.org/ 10.37394/232015.2020.16.47

[25] Ma, Y., (2020). Research on the Coupling Coordinative Degree of Tourism Development and Poverty Alleviation Effects in China based on the Model of DPSIR--An Example of Guizhou. International Journal of Circuits, Systems and Signal processing. 14. 637-645. https://doi.org/10.46300/9106.2020.14.82

[26] Altman, I.E. (1993) Corporate Financial Distress and Bankruptcy. A complete Guide to Predicting and Avoiding Distress and Profiting from Bankruptcy. New York. John Wiley and Sons

[27] Belak, V., Aljinović Barać, Ž. (2008) Tajne tržišta kapitala. Belak Excelences. Zagreb

[28] Hsu,T-H., Tsai I-H., (2020). The Effect of Tourism Development on Economic Growth in Taiwan: Export Growth as Mediator. 
International Journal of Circuits, Systems and Signal processing. 14.435-439. https://doi.org/10.46300/9106.2020.14.58

[29] Državni zavod za statistiku (2021). Available at: https://www.dzs.hr/default e.htm

[30] Hrvatska narodna banka (2021). Makroekonomska kretanja i prognoze, VI(10) Available at: https://www.hnb.hr/documents/20182/3973321/ hMKP_10.pdf/fd6d26e1-a556-115e-7f5a82cad6391a22

[31] European Centre for Disease Prevention and Control (ECDC) (2021). COVID -19 countries overviews. Available at: https://covid19country-overviews.ecdc.europa.eu/

[32] Eurostat (2020). Hrvatska ostvarila najveću razinu turističkih dolazaka i noćenja na Sredozemlju. Available at: https://ec.europa.eu/eurostat/web/productseurostat-news/-/DDN-20200513-2

[33] Roška, V., Kuvačić, D., Ribeiro, H. (2019). Accounting Indebtedness of Listed Companies in Croatia. Proceedings 39th International Scientific Conference on Economic and Social Development - "Sustainability from an Economic and Social Perspective". Varazdin Development and Entrepreneurship Agency. p.387-396

[34] Castanho, R.A., Couto, G., Pimentel, P., Carvalho, C., Sousa, A., Velarde, J.G., (2020) Assessing the Impacts of Public Policies Over Tourism in Azores Islands. A Research based on Tourists and Residents Perceptions. WSEAS Transactions on Environment and Development 16.744-753. htps://doi.org./10.37394/232015.2020.16.77

[35] World Bank (2020). The Global Economic Outlook During the COVID-19 Pandemic: A Changed World; Available at: https://www.worldbank.org/en/news/feature/202 0/06/08/theglobal-economic-outlook-duringthe-covid-19-pandemic-a-changed-world

[36] McKinsey (2020). COVID-19 tourism spend recovery in numbers. Available at: https://www.mckinsey.com/industries/travellogistics-and-transport-infrastructure/ourinsights/covid-19-tourism-spend-recovery-innumbers\#

[37] Ministarstvo turizma (2020). Turizam i Covid-19 - Pitanje od 1000 milijardi eura: Koliko će trajati kriza turizma uzrokovana COVID-19 pandemijom. Available at: https://mint.gov.hr/vijesti/turizam-i-covid-19pitanje-od-1000-milijardi-eura-koliko-ce-trajati- kriza-turizma-uzrokovana-covid-19-

pandemijom/21889

[38] Ministarstvo turizma (2021). Nacionalni plan oporavka i otpornosti. Available at: https://mint.gov.hr/nacionalni-plan-oporavka-iotpornosti/22463

\section{Creative Commons Attribution License 4.0 (Attribution 4.0 International, CC BY 4.0)}

This article is published under the terms of the Creative Commons Attribution License 4.0

https://creativecommons.org/licenses/by/4.0/deed.en_US 